\title{
ON THE NEMATOCYSTS OF HYDROMEDUSAE. III
}

\author{
By F. S. Russell, F.R.S. \\ Naturalist at the Plymouth Laboratory
}

(Text-figs. I-32)

The present paper is a continuation of the observations on the nematocysts of Hydromedusae and includes descriptions of the nematocysts of twelve species that I have not previously examined.

In two only of these species, Turritopsis nutricula and Aglantha digitalis var. rosea, was examination made on living material. For the remainder it has been necessary to use specimens preserved in formalin. Amongst these are a number of species whose classificatory position has a special interest. These species are not found at Plymouth and would in any event be difficult to obtain living as most of them are from deep water.

I am grateful to Mr J. H. Fraser, Dr H. B. Moore, and Mr W. J. Rees for kindly supplying me with some of these specimens. Certain of the other deep sea medusae were found among the collections of the late $\mathrm{Mr} \mathrm{E}$. T. Browne.

\section{ANTHOMEDUSAE \\ Turritopsis nutricula McCrady}

Observations were made on living material from Plymouth. There were two kinds of nematocysts, microbasic euryteles and desmonemes (Figs. I-4).

Euryteles: 8-10 $\times 4 \mu$ undischarged.

Desmonemes: 6-7 $\times 4-4.5 \mu$ undischarged, $4-5 \times 3 \mu$ discharged.

Both kinds of nematocysts were present in the marginal tentacles and in the nematocyst clusters along the margins of the mouth lips. In the tentacles there were only a few isolated euryteles, the desmonemes being very much the more numerous. In the margin of the mouth, however, the euryteles were abundant and the desmonemes a little less so.

\section{Bythotiara murrayi Günther}

I found in Mr Browne's collection a number of specimens collected by Dr Stanley Kemp from $1000 \mathrm{fm}$. at a position 50 miles north-west of Inishtearaght, Co. Kerry, on the west coast of Ireland, on November 3 I 904.

Two kinds of nematocysts were found, ? microbasic euryteles and desmonemes (Figs. 8-IO). Although many of the desmonemes were discharged, unfortunately none of the other kind of nematocyst were discharged; I could not therefore be absolutely certain whether they were microbasic euryteles. 
? Euryteles: 17-20 $\times$ I0-II $\mu$ undischarged.

Desmonemes: I3-I $4 \times 6 \mu$ undischarged, IO-II $\times 5-6 \mu$ discharged.

The distribution of the nematocysts was peculiar. On the primary marginal tentacles no nematocysts were to be seen along the whole tentacle until the terminal knob was reached. This large terminal cluster of nematocysts consisted entirely of desmonemes, most of which were discharged.

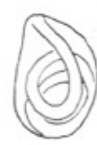

I

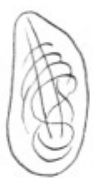

3

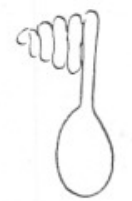

2

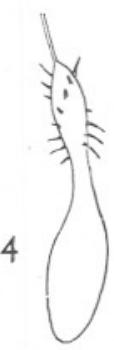

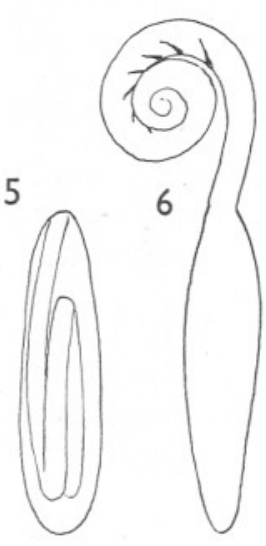

7

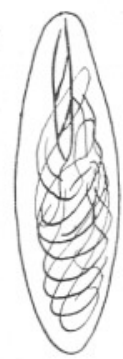

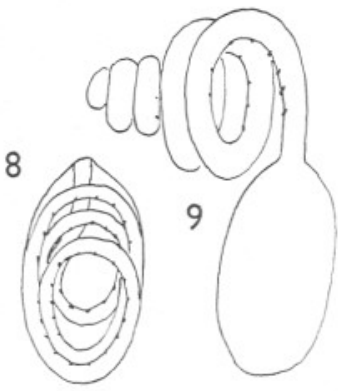

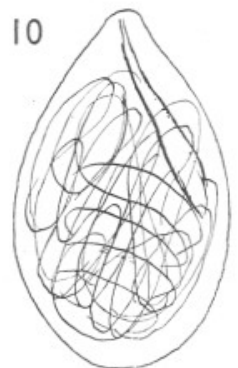

Figs. I-4. Turritopsis nutricula: 1,2 , desmonemes; 3, 4, microbasic euryteles. $\times$ ca. 2000 Figs. 5-7. Heterotiara anonyma: 5, 6, desmonemes; 7, ? microbasic eurytele. $\times$ ca. 2000 . Figs. 8-10. Bythotiara murrayi: 8, 9, desmonemes; Io, ? microbasic eurytele. $\times$ ca. 2000.

The secondary marginal tentacles were covered with nematocysts of both kinds over their whole length.

On one side of a secondary tentacle I saw one small discharged microbasic eurytele $6 \times 4 \mu$, but as I could find no others of this size I concluded that it had become attached to the tentacle from another medusa.

\section{Heterotiara anonyma Maas}

Dr H. B. Moore kindly gave me a very perfect specimen of this medusa caught near Bermuda. The specimen was $9 \mathrm{~mm}$. in height and had all eight tentacles intact. I examined the terminal cluster of one tentacle. It had nematocysts very similar in type to those of Bythotiara murrayi, namely, 
? microbasic euryteles and desmonemes (Figs. 5-7). As with Bythotiara, I could not be certain of the euryteles since none were discharged.

? Euryteles: I6-I $8 \times 4 \cdot 5-5 \mu$ undischarged.

Desmonemes: $17-\mathrm{I} 8 \times 4 \mu$ undischarged, $\mathrm{I} 6-\mathrm{I} 7 \times 3.5 \mu$ discharged.
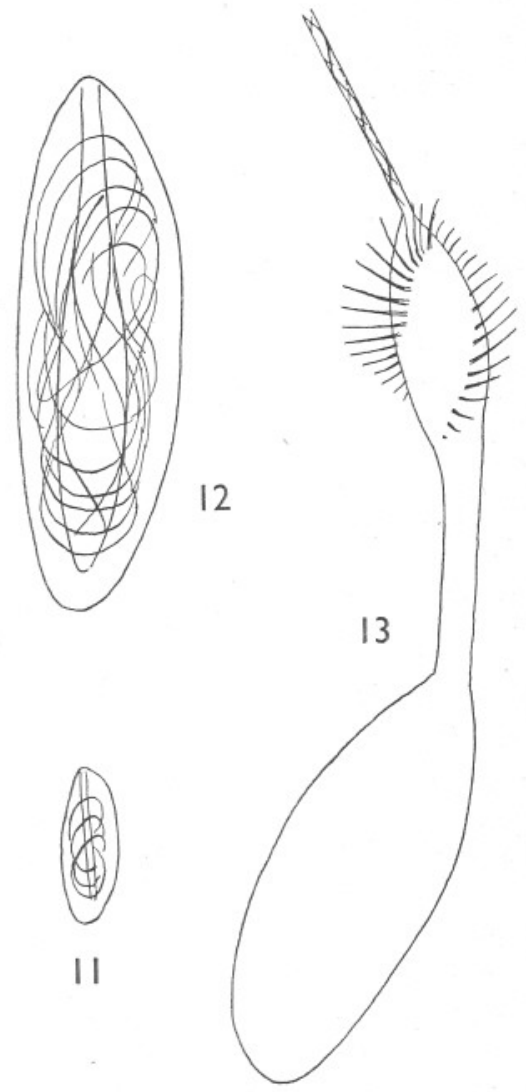

II

Figs. II-I3. Tiaranna rotunda: microbasic euryteles. $\times c a .2000$.

Figs. I4-I7. Chromatonema rubrum: microbasic euryteles. $\times c a .2000$.

Tiaranna rotunda (Quoy \& Gaimard)

$\mathrm{Mr}$ W. J. Rees kindly allowed me to examine fragments of two specimens sent to him by Mr J. Hult and caught in Trondhjeimsfjord on August 231937.

Both in the marginal tentacles and in the marginal cordylus-like structures only one kind of nematocyst could be found, microbasic euryteles (Figs. II-I3). These were, however, of two sizes, large and small.

Euryteles: two sizes.

Large: $24-27 \times 8-9 \mu$ undischarged.

Small: $8-9 \times 3 \mu$ undischarged. 


\section{Chromatonema rubrum Fewkes}

I found one specimen of this species in Mr Browne's collection. It was taken from $1000 \mathrm{fm}$. at a position 50 miles north-west of Eagle Island, Co. Mayo, on the west coast of Ireland by Dr Kemp, on August II I904. None of the mouth was available for examination but there were a few marginal tentacles. These contained nematocysts of only one kind, microbasic euryteles (Figs. I4-I7). As in Tiaranna rotunda these were of two sizes, large and small. Euryteles: two sizes.

Large: $19-20 \times 6 \mu$ undischarged.

Small: 9-10 $\times 2 \cdot 5-3 \mu$ undischarged.

\section{ON THE AfFinities of TIARANNA AND CHROMATONEMA}

The fact that Chromatonema rubrum possesses only microbasic euryteles and that these resemble so closely those of Tiaranna rotunda is of considerable interest. It seems to imply that the affinities of Chromatonema are closer to the Anthomedusae than to the Leptomedusae.

That Chromatonema belongs to a borderline group between the two is fully realized (see e.g. Kramp, I919, I920; Bigelow, I938), and the difficulty has been to decide whether it should be placed with the Pandeidae in the Anthomedusae or the Laodiceidae in the Leptomedusae. The form of its nematocysts strengthens the argument that Chromatonema would be nearer its right position if placed in the Anthomedusae, but I do not think it should be put in the Pandeidae. Bigelow (1938) suggests that it may deserve a separate family, but there is another genus which also requires to be considered and that is Tiaranna, which has up till now been included among the Pandeidae. This genus, like Chromatonema, is remarkable in having medusae with marginal cordylus-like structures, and the two genera likewise agree in the form of their marginal tentacles. I suggest that Tiaranna and Chromatonema are placed together in a new family, the Tiarannidae. In doing this it is necessary to reiterate with Kramp (I926, p. 69) that Tiaranna affinis should not belong to the genus Tiaranna. In the form of its marginal tentacles it resembles more closely Leuckartiara, but from the form of its stomach and gonads it is probably necessary to make a new genus for which I propose the name Annatiara, which was suggested to me by Dr G. P. Bidder.

Ranson (1936) has already placed Chromatonema in the Anthomedusae, but his inclusion of the genus in the Williidae cannot stand. Kramp (I939) has shown the probable relationship of the Williidae with the medusae of his newly erected Limnomedusae. In spite of the fact that the nematocysts of Willia are so remarkable ${ }^{\star}$ I agree with Kramp that we cannot as yet place too much stress on the use of nematocysts as classificatory characters. But if the characters of the nematocysts reinforce indications that are already supplied by other characters I think we are quite entitled to use them as

* I have seen in preserved material that the nematocyst patches on the exumbrella of the medusa Willia stellata contain the macrobasic mastigophores characteristic of the hydroid. 
corroborative evidence. In this respect the differences between the nematocysts of Chromatonema and Laodicea are quite conclusive. The nematocysts of Laodicea are typically Leptomedusan (see below), and in no species of Leptomedusae have microbasic euryteles as yet been found, except for the doubtful form in the aberrant Dipleurosoma described below. The further descriptions given below also show that the nematocysts of Ptychogena and Staurophora are Leptomedusan in character, although they appear to lack the atrichous haplonemes which are present in so many other species.

\section{LEPTOMEDUSAE \\ Ptychogena crocea Kramp \& Damas}

Mr W. J. Rees kindly allowed me to see specimens of this medusa which he had collected in Norway. They had only one kind of nematocyst, microbasic mastigophores (Figs. I8-I9).

Mastigophores: $\mathrm{I} 4-\mathrm{I} 5 \times 2 \cdot 5 \mu$ undischarged.

\section{Laodicea undulata (Forbes \& Goodsir)}

The examination was made on preserved specimens collected in the English Channel. There were two kinds of nematocysts, microbasic mastigophores and atrichous haplonemes (Figs. 28-3I).

The mastigophores were of two sizes, large and small.

Mastigophores: two sizes.

Large: I6-I $8 \times 5 \cdot 5 \mu$ undischarged.

Small: I I-I $3 \times 3-4 \mu$ undischarged, IO-I I $\times 2.5 \mu$ discharged.

Atriches: 10-I2 $\times 4 \cdot 5-5 \mu$ undischarged.

The large mastigophores were extremely rare, and at most only an occasional one or two were to be found in the proximal region of a tentacle. In general appearance all the nematocysts were typically Leptomedusan.

\section{Staurophora mertensi Brandt}

Some specimens were kindly sent to me by $\mathrm{Mr}$ J. H. Fraser, collected from $56^{\circ} 02^{\prime}$ N., $2^{\circ} 30^{\prime}$ W., on July 2 I 1937 . Both on the mouth lips and marginal tentacles there was only one kind of nematocyst, microbasic mastigophores (Figs. 20-2I).

Mastigophores: IO-I I $\times 3-3.5 \mu$ undischarged.

\section{Dipleurosoma typicum Boeck}

Examination was made on material in Mr Browne's collection from Valentia. There was only one type of nematocyst so far as I could see, ? microbasic euryteles (Figs. 22, 23). The hamp of the discharged nematocyst was only very slightly expanded distally and its sides were very nearly parallel, so that it might almost as well have come under the category of microbasic mastigophores.

? Euryteles or mastigophores: 9-10 $\times 3 \mu$ undischarged. 


\section{Melicertum octocostatum (M. Sars)}

Examination was made on material in Mr Browne's collection from Lamlash Bay, Isle of Arran. There were two kinds of nematocysts, microbasic mastigo-
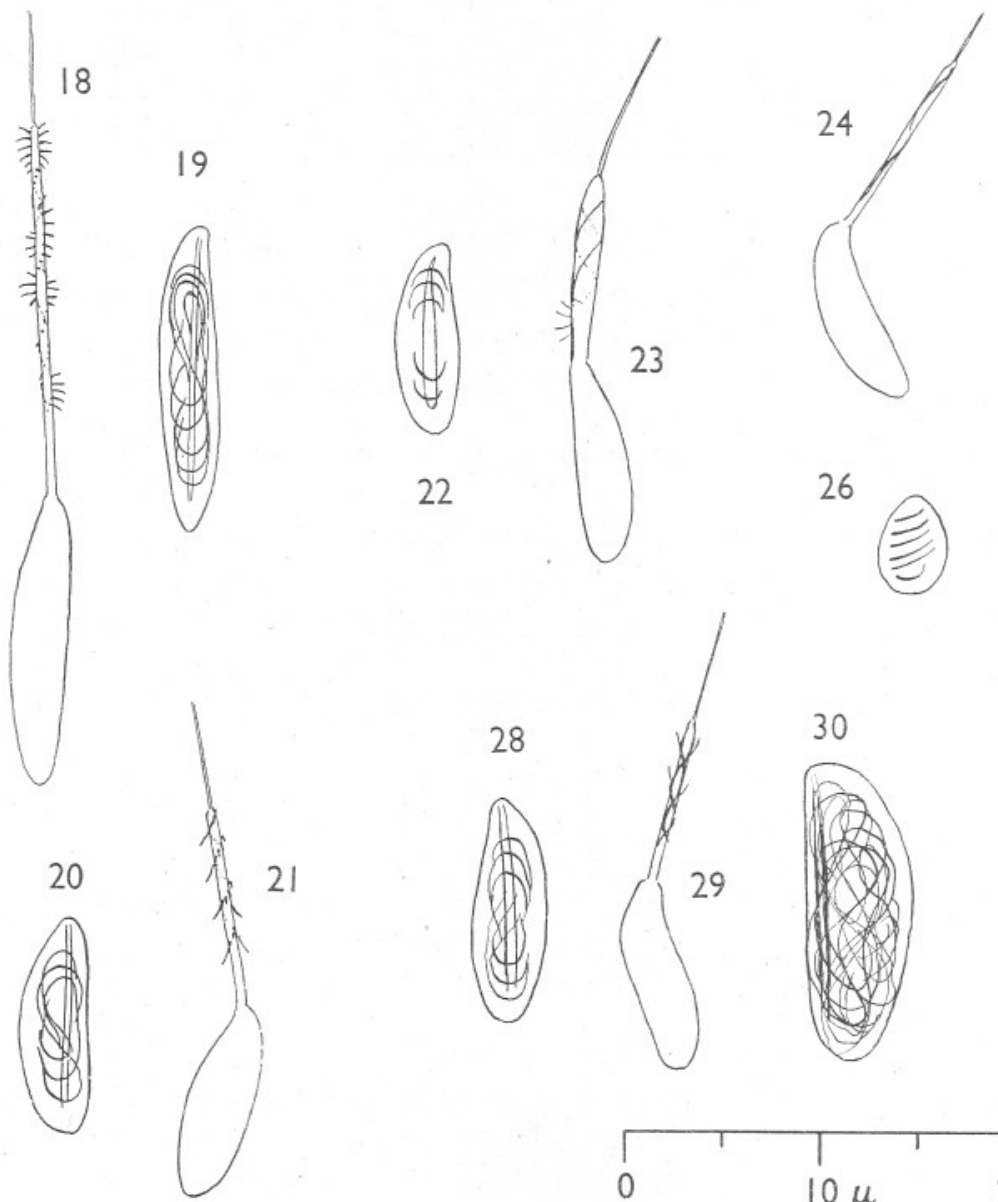

25
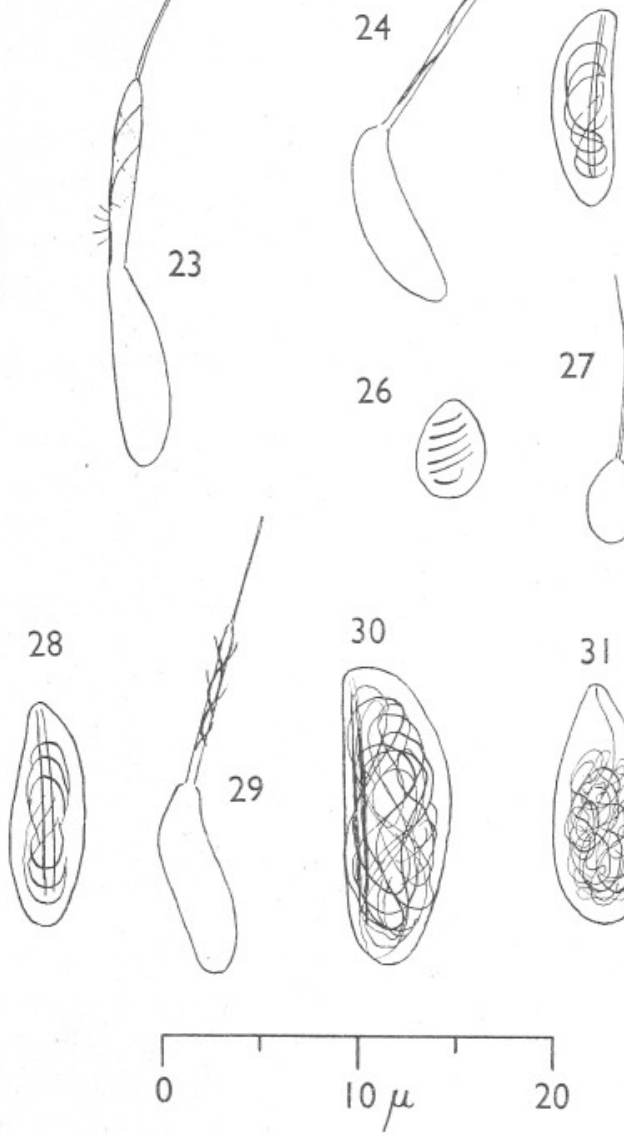

26
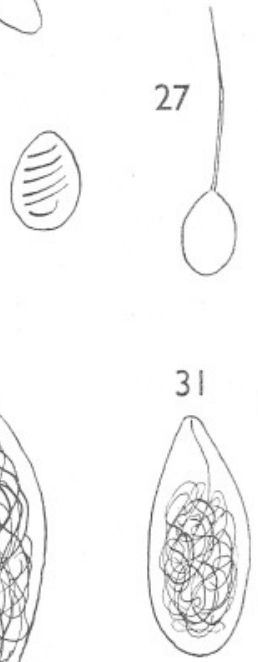

Figs. I8, I9. Ptychogena crocea: microbasic mastigophores. $\times c a .2000$.

Figs. 20, 21. Staurophora mertensi: microbasic mastigophores. $\times$ ca. 2000 .

Figs. 22, 23. Dipleurosoma typicum: ? microbasic euryteles or mastigophores. $\times c a .2000$.

Figs. 24-27. Melicertum octocostatum: 24, 25, microbasic mastigophores; 26, 27, atrichous haplonemes. $\times c a .2000$.

Figs. 28-31. Laodicea undulata: 28-30, microbasic mastigophores; 3I, atrichous haploneme. $\times c a .2000$.

phores and what appeared to be atrichous haplonemes of rather an unusual form (Figs. 24-27). In their undischarged state the atrichous haplonemes showed six well defined coils of the basal part of the thread, differing from 
the usual irregular coiling shown in typical Leptomedusan nematocysts of this kind.

Mastigophores: IO-II $\times 3 \mu$ undischarged.

Atriches: $5 \times 3-3.5 \mu$ undischarged, $4 \times 3 \mu$ discharged.

Aequorea floridana (L. Agassiz)

Dr H. B. Moore kindly gave me a specimen of this medusa caught near Bermuda. The structural details of the specimen were as follows: diameter of umbrella, $23 \mathrm{~mm}$.; diameter of stomach, $5 \mathrm{~mm}$.; number of radial canals, I6; number of marginal tentacles, 3-5 per sector, or ca. 64 in all.

There were two kinds of nematocysts, ? basitrichous haplonemes or microbasic mastigophores (none were discharged) and atrichous haplonemes.

? Basitriches: IO-I I $\times 2 \cdot 5-3 \mu$ undischarged.

Atriches: I3-I4 $\times 6 \cdot 5-7 \cdot 5 \mu$ undischarged.

The nematocysts were quite similar in shape to those I have described for Aequorea forskalea and $A$. vitrina (Russell, I939), but the atrichous haplonemes were smaller than in either of those species.

\section{TRACHYMEDUSAE}

\section{Aglantha digitalis (O. F. Müller) var. rosea (Forbes)}

Examination was made on several living specimens 5-II $\mathrm{mm}$. in height collected at Plymouth in January and February 1939. The mouth only was examined, and unfortunately I have seen no more specimens since; a close study of their nematocysts might prove interesting. There are apparently two kinds of nematocysts, stenoteles and microbasic euryteles, but there are also a number of nematocysts intermediate between the two kinds of which the fully formed stenoteles were usually the larger (Fig. 32).

Stenoteles-Euryteles: 8-I3 $\times 6-$ I I $\mu$ undischarged, 7-IO $\times 5-9 \mu$ discharged.

The stenoteles were quite typical of this kind of nematocyst (Fig. 32a,b), and the fully formed microbasic euryteles would likewise have been classified as such if seen alone (Fig. $32 f$ ). But the euryteles were apparently formed as a result of the reduction of the stenoteles. This seems to have been accomplished by a reduction of the dilated portion of the hamp between the large basal spines and the capsule, so that these spines were contiguous with the capsule itself (Fig. 32c). In more advanced stages of reduction these large spines show signs of contortion (Fig. $32 d$ ) or incomplete development (Fig. 32e) and in some they had entirely disappeared.

These nematocysts of Aglantha have an interesting bearing on the possible lines of evolution among nematocysts in general. Weill (I934, p. 98 seq.) has sketched the possible evolution of nematocysts in which he suggests that the evolution of the stomocnides has been in general in the direction of increased complexity. In these specimens of Aglantha we have an indication of the evolution of a microbasic eurytele from a stenotele actually taking place by a reduction of the basal portion of the hamp of the stenotele and its spines, 
with a consequent decrease in size of the nematocyst as a whole. Weill has already concluded that it is not possible to say whether atrichous haplonemes are derived from holotrichous haplonemes by progressive reduction of spines or the holotriches from the atriches by progressive development of spines. It seems that the nematocysts of Aglantha afford definite evidence that evolution may have proceeded as well by reduction as by elaboration in other kinds of nematocysts.
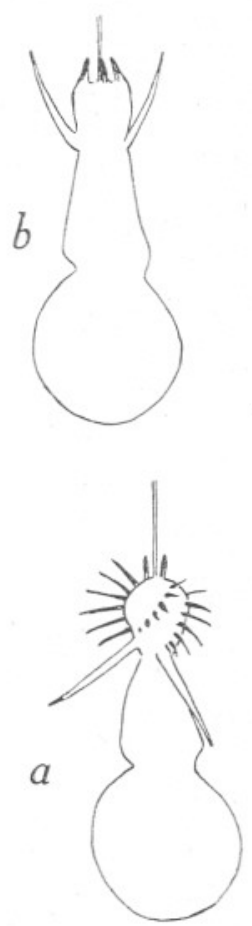

Fig. 32. Aglantha digitalis var. rosea: stenoteles and microbasic euryteles and transitional forms. $\times c a .2000$
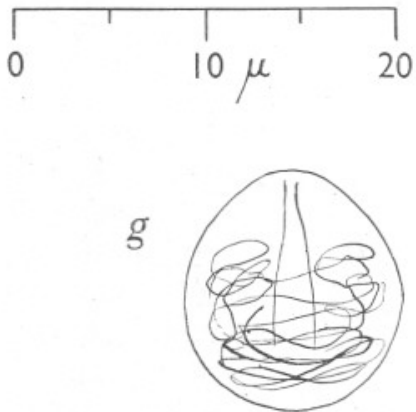
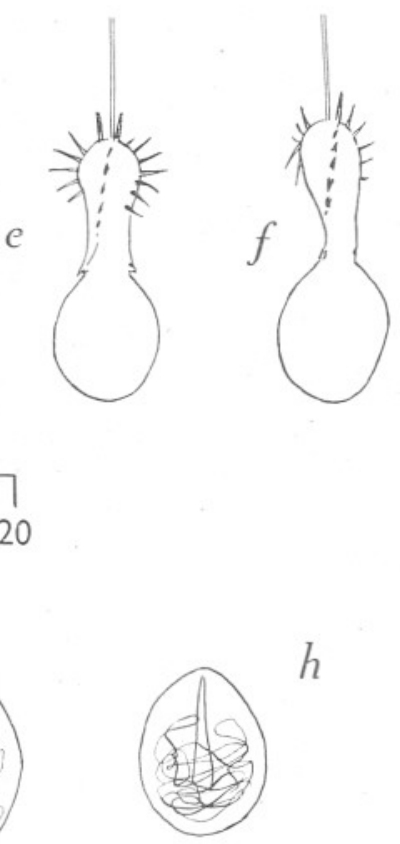

$h$

\section{SUMMARY}

The nematocysts of five species of Anthomedusae, six species of Leptomedusae, and one Trachymedusa are described.

In view of the additional support supplied by characters of its nematocysts it is suggested that the genus Chromatonema should be placed with Tiaranna in a new family, the Tiarannidae, in the Anthomedusae.

Evidence on the possible evolution of microbasic euryteles from stenoteles is afforded by the nematocysts of Aglantha. 


\section{REFERENCES}

Bigelow, Henry B., I938. Plankton of the Bermuda Oceanographic Expeditions. VIII. Medusae taken during the years 1929 and 1930. Zoologica, New York, Vol. xxiII, Pt. 2, No. 5, pp. 99-189.

Kramp, P. L., I9I9. Medusae. Part I. Leptomedusae. Danish Ingolf-Expedit., Vol. v, Pt. 8, pp. I-III.

I920. Anthomedusae and Leptomedusae from the "Michael Sars" North Atlantic Deep-sea Expedition, I910. Rep. Sci. Res. "M. Sars” N. Atl. Expedit. I9Io, Vol. III, Pt. II (I913-2I), I4 pp. (I932).

I926. Medusae. Part II. Anthomedusae. Danish Ingolf-Expedit., Vol. v, Pt. Io, pp. I-IO2.

— I939. Occasional notes on Coelenterata. III. Vidensk. Medd. Naturh. Foren. Kojb., Bd. I03, pp. 503-I6.

Ranson, Gilbert, I936. Méduses provenant des Campagnes du Prince Albert Ier de Monaco. Rés. Camp. Sci. Monaco, Fasc. xcII, pp. I-239.

Russell, F. S., I939. On the nematocysts of Hydromedusae. II. Fourn. Mar. Biol. Assoc., Vol. xxIII, pp. 347-59.

WeILl, ROBERT, I934. Contribution à l'étude des cnidaires et de leurs nématocystes. I. Recherches sur les nématocystes (Morphologie-Physiologie-Développement). Trav. Stat. Zool. Wimereux, Tome x, pp. I-347. 